\title{
The Improvement of Wear and Impact Resistance of High Chromium White Cast Iron for Crusher
}

\author{
R. S. Prayogo* \\ L. D. Setyana
}

Vocational College Universitas Gadjah Mada, Yogyakarta 55281, Indonesia

Email:

ridhosabdo@gmail.com

\section{Keywords}

high chromium white cast iron, crusher, heat treatment, wear rate.

\begin{abstract}
Crusher is a component of heavy equipment used to break rocks or solid materials into a needed size. Crusher that is made of high chromium white cast iron will endure friction and impact forces. The quality improvement of the crusher is needed for enduring its service life. This research is conducted to determine the influence of heat treatment on the wear and impact resistance of the crusher. The material used in this research was high chromium white cast iron with some main compositions such as $18.5 \%$ wt $\mathrm{Cr}, 2.1 \%$ wt $\mathrm{C}$, and $2.8 \%$ wt Ni. The heat treatment carried out was austenitization at a temperature of $1000^{\circ} \mathrm{C}$, followed by the quenching, quenchingtempering, normalizing, and annealing process. The tests carried out for the characterization of mechanical properties were Vickers hardness, impact, and wear rate. Meanwhile, observation was conducted to examine the microstructure of the specimen. Based on the observations, the microstructure of the specimen is dominated by M7C3 eutectic carbide, retained austenite and martensite. The highest hardness of the high chromium white cast iron (788 VHN) is a specimen with austenitizing-quenching (up $16 \%$ compared to normalizing specimens) and gradually decreases (up to $12 \%$ after the $450^{\circ} \mathrm{C}$ tempering. The highest wear resistance $\left(8.1 \mathrm{E}-6 \mathrm{~mm}^{3} / \mathrm{kg} . \mathrm{m}\right)$ is the specimen with tempering at $450^{\circ} \mathrm{C}$. The highest impact strength $(0.055$ $\mathrm{J} / \mathrm{mm}^{2}$ ) occurs in the normalizing process. Hence, the heat treatment that can produce optimal properties to be applied in the crusher is tempering with the temperature of $450^{\circ} \mathrm{C}$.
\end{abstract}




\section{Introduction}

Crusher is a heavy equipment component that is used to break rock or solid material into the needed size. High chromium white cast iron is a material that has high wear resistance and is tough to accept impact loads. This material is suitable as a crusher and experiences friction and impact when used frequently. Therefore, the crusher must have high wear and impact resistance for longer service life. The mechanical properties of a crusher with high chromium white cast iron can be improved by heat treatment (Long, S.Y et al., 2006).

High chromium white cast iron is a material suitable for use in work environments with friction and impact. High chromium white cast iron has high hardness, high wear resistance, and relatively cheap manufacturing costs (Furqon, M., dan Sugiyana, D, 2011). High chromium white cast iron based on the ASTM A532-10 standard is a material with the main content of $11-30 \% \mathrm{wt} \mathrm{Cr}$ and 1.8-3.6\% wt $\mathrm{C}$ as well as accompanying elements of molybdenum, manganese, copper, and nickel carbon. The chromium content and some of its accompanying elements, such as nickel and molybdenum, make the material hard and resistant to wear. The chromium element also acts as a barrier to the formation of graphite in white cast iron materials and forms chrome carbides. Carbides generally have high hardness (1200-1800 VHN) and excellent wear resistance, making them suitable for grinding ball materials in ball mills (Shofi, A et al., 2013). Heat treatment causes a change in the volume of chrome carbide grains. The austenitization treatment causes the chromium element to dissolve and react with carbon that affected secondary chromium carbides formation (Bedolla et al., 2003).

The structure formed in high chromium white cast iron material consists of eutectic carbide $\mathrm{M}_{7} \mathrm{C}_{3}$ in the austenite matrix. Thermal hardening treatment allows the formation of martensite and chrome carbide $\left(\mathrm{Cr}_{7} \mathrm{C}_{3}\right)$. This typical formation is due to the chromium element dissolved in the austenite under as-cast conditions reacts with the carbon at the austenite temperature, which causes the formation of new chrome carbides $\left(\mathrm{Cr}_{7} \mathrm{C}_{3}\right)$ or secondary carbides. Chromium carbide has a layered structure and fine lamellar. The fine lamellar structure has better toughness when compared to carbides which have massive and coarse structures, such as cementite carbide $\left(\mathrm{Fe}_{3} \mathrm{C}\right)$. The structure of the coarse chromium carbide tends to have less impact on the mechanical properties of metal materials. In high chrome alloy white cast iron, the fine carbide structure in the matrix will provide an excellent combination of hardness and toughness compared to coarse carbide structures (Shofi, A et al., 2013).

The microstructure of high chromium white cast iron after quenching is dominated by carbide and residual austenite. The types of carbides formed are $\mathrm{M}_{7} \mathrm{C}_{3}\left(\mathrm{Cr}_{7} \mathrm{C}_{3}\right.$, $\left.(\mathrm{Fe}, \mathrm{Cr})_{7} \mathrm{C}_{3}, \quad(\mathrm{Fe}, \mathrm{C})_{3} \mathrm{C}, \quad(\mathrm{Fe}, \mathrm{Cr})_{23} \mathrm{C}_{6}\right)$. The combination of microstructure and hardness values can be determined after austenitizingquenching so that the number of carbide increases and the austenite phase decreases. The secondary carbide $\mathrm{M}_{7} \mathrm{C}_{3}$ is precipitated continuously during the decrease in temperature so that the austenite phase decreases and the secondary phase $\mathrm{M}_{7} \mathrm{C}_{3}$ increases gradually (Li, D. 2009).

The type of heat treatment that can produce wear resistance and toughness according to the application requirements still needs to be done to be applied in crusher products. This research aims to determine the effect of heat treatment of high chromium white cast iron on its wear and impact resistance.

\section{Materials and Methods}

This research used high chromium white cast iron material which is used as a material for making crushers. The chemical composition can be seen in Table 1, with the main content being $18.5 \%$ wt $\mathrm{Cr}, 2.1 \%$ wt $\mathrm{C}$ and $2.8 \%$ wt $\mathrm{Ni}$. This alloy is in accordance with the material composition of high chromium white cast iron based on ASTM A532-10 standards. Chemical composition testing using spectrometry. 
Table 1. Chemical composition of high chromium white cast iron

\begin{tabular}{llll}
\hline Elements & $(\% \mathrm{wt})$ & Elements & $(\% \mathrm{wt})$ \\
\hline $\mathrm{Fe}$ & 72,68 & $\mathrm{~V}$ & 0,16 \\
\hline $\mathrm{S}$ & 0,03 & $\mathrm{Mn}$ & 0,65 \\
\hline $\mathrm{C}$ & 2,10 & $\mathrm{Mo}$ & 0,840 \\
\hline $\mathrm{Ni}$ & 2,81 & $\mathrm{~W}$ & 0,30 \\
\hline $\mathrm{Nb}$ & 0,07 & $\mathrm{P}$ & $>0,04$ \\
\hline $\mathrm{Si}$ & 1,55 & $\mathrm{Cu}$ & 0,26 \\
\hline $\mathrm{Cr}$ & 18,50 & $\mathrm{Ti}$ & 0,04 \\
\hline
\end{tabular}

Heat treatment that is carried out was austenitization at a temperature of $1000^{\circ} \mathrm{C}$ (Fairhust, W., dan Rohrig, K, 1974). The heat treatment process then continued with several variations, namely: quenching, quenchingtempering $300^{\circ} \mathrm{C}$ for 3 hours, quenchingtempering $450^{\circ} \mathrm{C}$ for 3 hours, normalizing, and annealing. Each variation was carried out with three specimens.

Tests carried out to characterize the mechanical properties are the Vickers hardness test (universal hardness tester), impact (impact tester), and wear rate (universal wear). Observation of the microstructure was carried out using a metallurgical microscope. Specimen preparation was carried out by sanding (\# 180

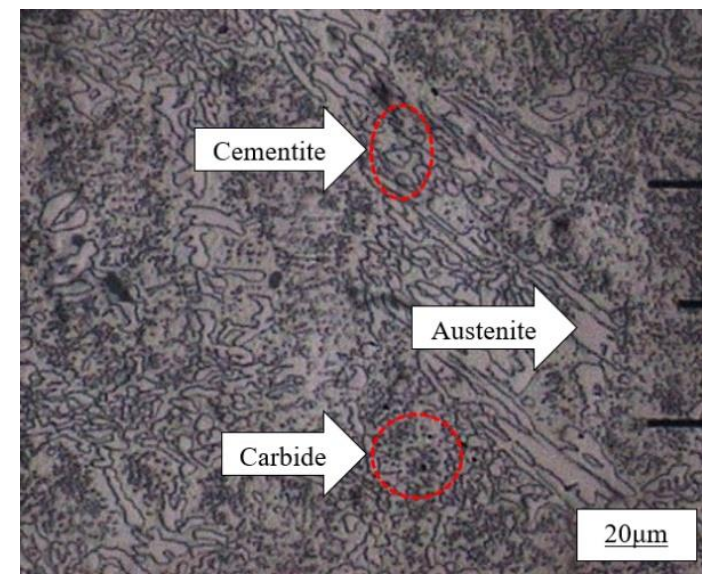

a. Quenching to \# 1000), polishing and etching (5\% wt $\mathrm{HNO}_{3}$ ) processes when observing the microstructure.

\section{Results and Discussion}

The microstructure in the form of eutectic carbide $\mathrm{M}_{7} \mathrm{C}_{3}$ and austenite is seen to dominate, as shown in Figure 1. The microstructure formed is similar to previous observations (Aziz et al., 2015). $\mathrm{M}_{7} \mathrm{C}_{3}$ carbide is formed as a result of the thermal hardening process and the decrease in the amount of austenite. Martensite structures are also formed in small amounts during the austenitization - quench treatment. The difference in heat treatment causes different grain sizes. The specimens with quenchaustenitization treatment (Figure 1.a) had a smaller and denser grain size of retained austenite than after the tempering process. The austenite structure of specimens with tempering treatment at $300^{\circ} \mathrm{C}$ has a wider size than tempered at $450^{\circ} \mathrm{C}$, but the chromium carbide is more visible, as shown in Figures 1.b and 1.c. The annealing treatment causes the austenite grain boundaries to be firmer with more chromium carbide than the normalizing treatment, as shown in Figures 1.d and 1.e.

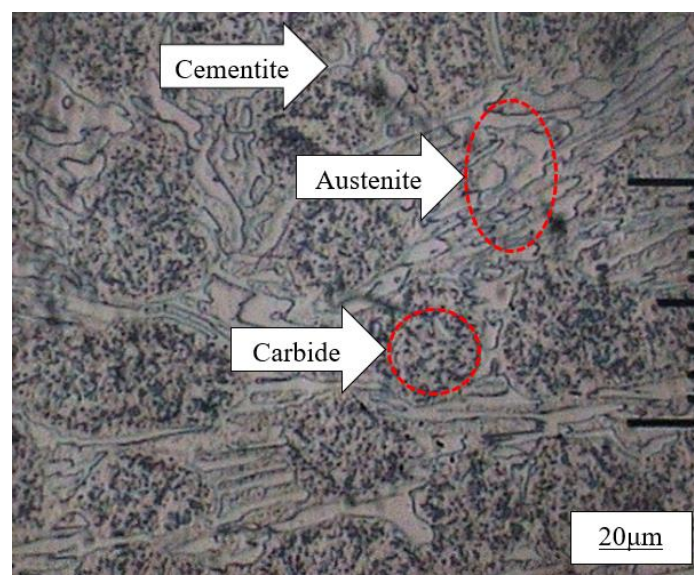

b. Temper $300^{\circ} \mathrm{C}$ 


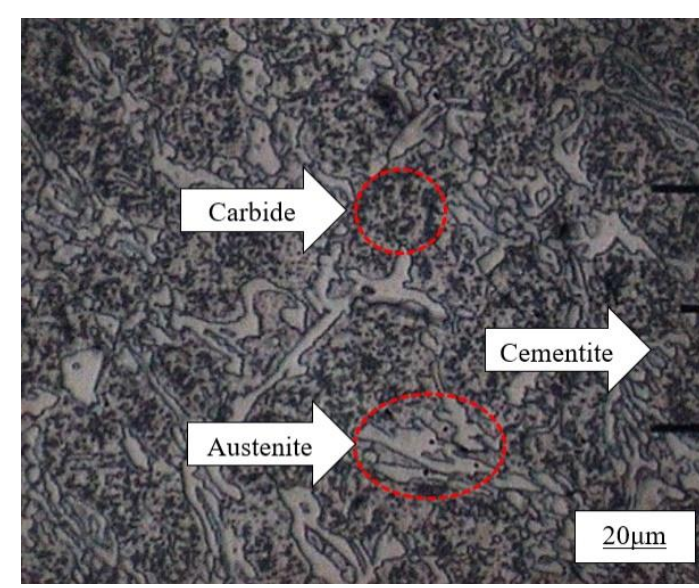

c. Temper $450^{\circ} \mathrm{C}$

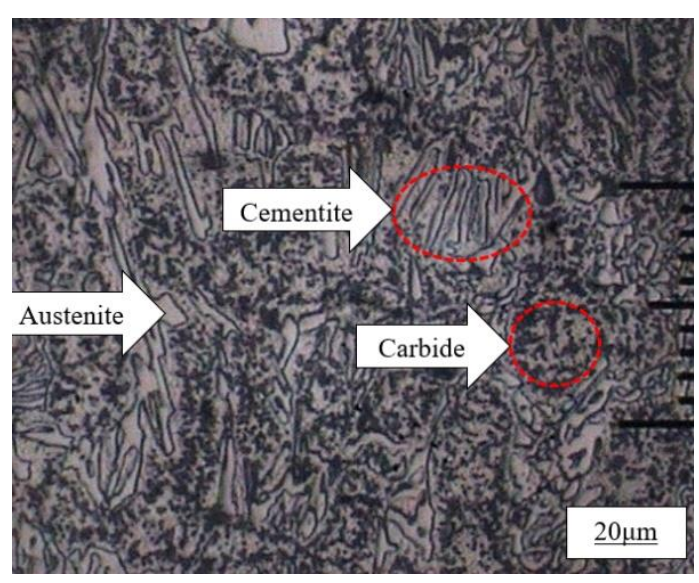

d. Normalizing

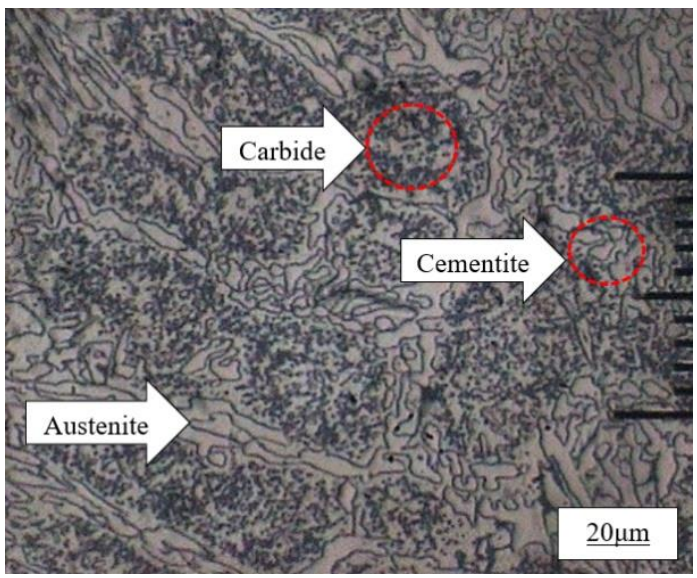

e. Annealing

Figure 1. The microstructure after heat treatment

The high chromium content (18.5 $\mathrm{wt} \%$ ) slows down graphing and causes cementite to form. Cementite has high hardness because it is an iron carbide $\left(\mathrm{Fe}_{3} \mathrm{C}\right)$. Some of the cementite can turn into martensite after quenching. The tempering process causes some of the trapped carbon to come out to form prime martensite. In addition, the holding time of 3 hours during the tempering process causes the size of the cementite grains to become larger and the distance away, as shown in Figures $1 \mathrm{~b}$ and 1c. The small, diffuse size of cementite grains will increase the hardness but will cause brittleness. The formation of chrome carbides around the cementite also increases hardness. However, coarser carbides will cause the brittleness of the material, whereas finer chrome carbides increase toughness.
The highest hardness (788 VHN) was a specimen with quenching, as shown in Figure 2. Fast cooling carried out on high chromium white cast iron resulted in the formation of $\mathrm{M} 7 \mathrm{C} 3$ carbide (Cr7C3, (Fe, $\mathrm{Cr}) 7 \mathrm{C} 3, \quad(\mathrm{Fe}, \mathrm{C}) 3 \mathrm{C}, \quad(\mathrm{Fe}, \mathrm{Cr}) 23 \mathrm{C} 6)$ and martensite (Li, D. 2009). Hard carbide is formed with a small size but evenly. Rapid cooling also causes trapped carbon to form a martensite structure which increases hardness. Tempering at temperatures of $300 \mathrm{oC}$ and $450 \mathrm{oC}$ reduced the hardness by $15 \%$ and $12 \%$ compared to after the quenching process. Decreased hardness is observed due to the formation of prime martensite during the tempering process. Tempering also causes cementite to grow in size and distance itself.

The tempering causes the austenite grain boundaries to enlarge at a distance so 
that the hardness decreases compared to after the quenching. In addition, the holding time during the tempering causes trapped carbon to be released so that prime martensite is formed with a lower hardness than martensite. The lowest hardness value occurred in specimens with annealing ( $605 \mathrm{VHN})$ because the slow cooling process made the granules of the austenite structure larger and coarser.

Chrome as the main alloying element $(18.5 \%)$ acts as an alloying element that increases the hardness, wear-resistance, and corrosion resistance of white cast iron. The composition of $\mathrm{Ni}(2.814 \%)$ and $\mathrm{Si}(1.549 \%)$ will improve the heat and oxidation resistance of the material, in addition to increasing the toughness, hardness, and hardening depth (Clark, D.S., dan Varney, W. R., 1952).

The highest wear rate $(4.25 \mathrm{E}-5$ $\mathrm{mm}^{3} / \mathrm{kg} . \mathrm{m}$ ) occurred in specimens with quenching, as shown in Figure 3. The wear rate decreased (wear resistance increased) after the tempering. The temper of $300 \mathrm{oC}$ and $450 \mathrm{oC}$ increase wear resistance by $43 \%$ and $80 \%$ compared to after quenching.

The specimens after quenching have a high wear rate because the structure is dominated by carbides which are hard but easily abrasion when there is friction. Selflubrication ability decreased due to the less cement. Meanwhile, the $450 \mathrm{oC}$ tempered specimen had the lowest wear rate compared to other treatments. The tempering caused the formation of large cementite structures. Cementite $\left(\mathrm{Fe}_{3} \mathrm{C}\right)$ is an iron carbide that is slippery and hard. The wide cementite size makes the material more wear-resistant.

The specimens with the normalizing had the highest impact resistance $(0.055$ $\left.\mathrm{J} / \mathrm{mm}^{2}\right)$, as shown in Figure 4. The annealing had the lowest impact strength $\left(0.038 \mathrm{~J} / \mathrm{mm}^{2}\right)$. The specimens with tempered of $450 \mathrm{oC}$ have $14 \%$ lower impact strength than the specimens with tempered of $350 \mathrm{oC}$.

The normalizing causes the formation of carbides and the remaining austenite to spread out evenly due to the normal cooling. The carbide that is formed is more refined than the fast cooling. This causes increased toughness (Shofi, A et al., 2013). When cooling, M7C3 secondary carbide is deposited continuously during a decrease in temperature, the austenite phase decreases, and the M7C3 secondary phase increases gradually (Li, D. 2009).

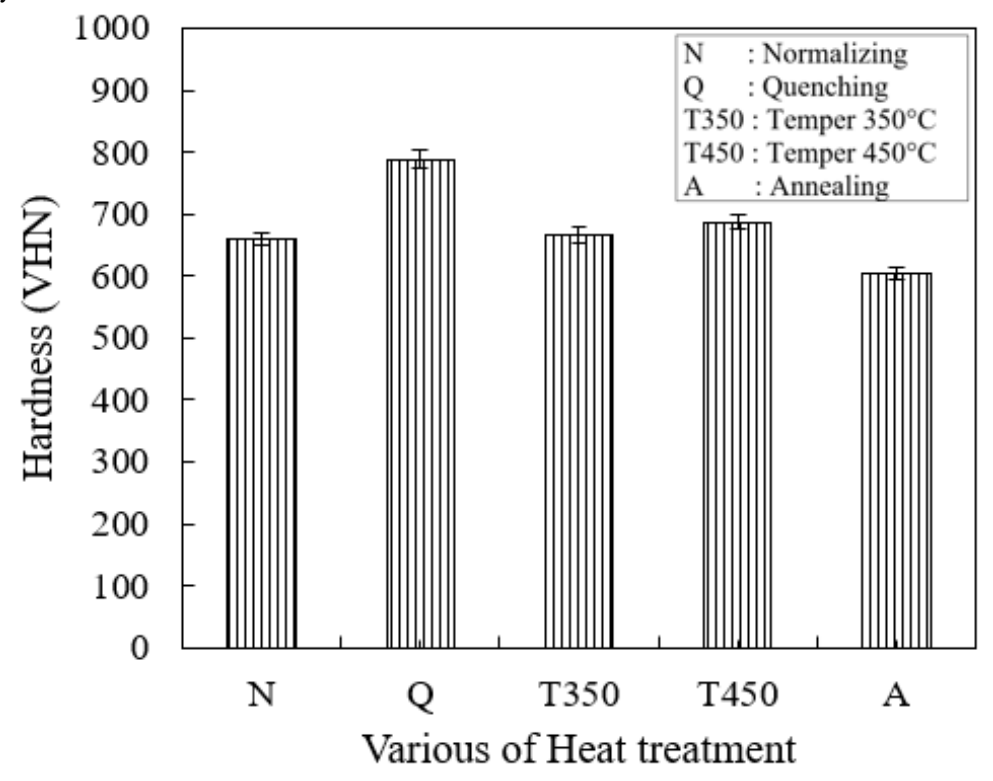

Figure 2. The hardness of the specimen after heat treatment 


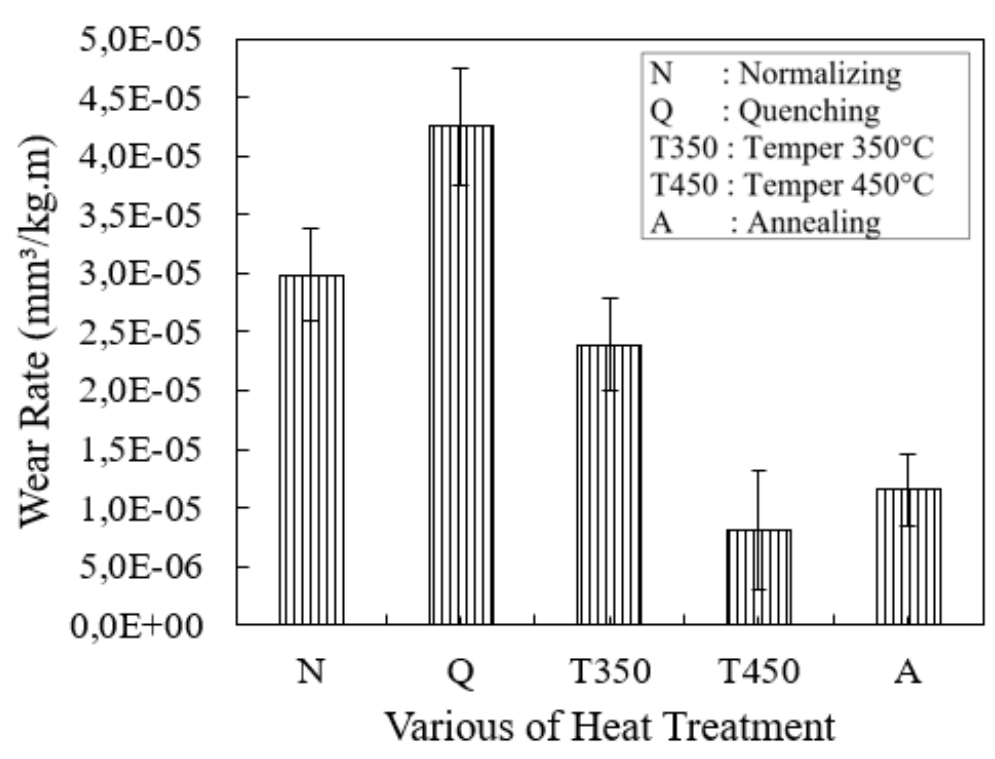

Figure 3. Wear rate after heat treatment

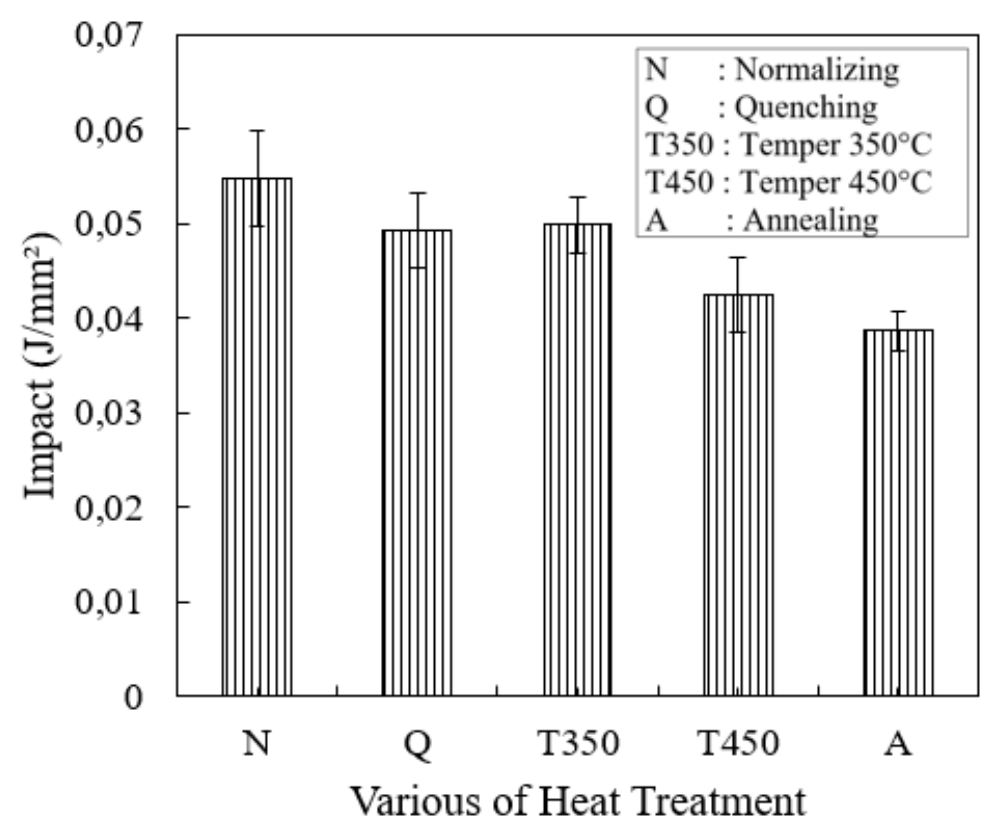

Figure 4. Impact value after heat treatment

\section{Conclusion}

The conclusions based on the analysis of the research results:

1. The highest hardness of high chromium white cast iron $(788 \mathrm{VHN})$ is the specimens with quenching (up 16\% compared to normalizing) and gradually decreased (up to $12 \%$ ) after tempering $450^{\circ} \mathrm{C}$.

2. The highest wear resistance (8.1E-6 $\left.\mathrm{mm}^{3} / \mathrm{kg} . \mathrm{m}\right)$ is the specimens with tempering of $450^{\circ} \mathrm{C}$

3. The highest impact strength $(0.055$ $\mathrm{J} / \mathrm{mm} 2$ ) occurred in specimens with normalizing. 


\section{References}

Aziz, A. E., Zohdy, K., Saber, D., dan Sallam, H.E.M. 2015. Wear and Corrosion Behavior of High-Cr White Cast Iron Alloys in Different Corrosive Media. Journal Bio Tribo Corrosion. Vol. 1:25. Hal. 1-12.

Bedolla, K. A., Arias, L., dan Hernandez, B. 2003. Kinetics of Secondary Carbides Precipitation in a High-Chromium White Cast Irons. Journal of Materials Engineering and Performance. Hal. 371-382.

Clark, D.S., dan Varney, W. R. 1952. Physical Metallurgy for Engineers. Van Nostrand. New York.

Fairhust, W., dan Rohrig, K. 1974. AbrasionResistant High-Chromium White Cast Irons. Foundry Trade Journal. Vo. 5. Hal. 685-695.

Furqon, M., dan Sugiyana, D. 2011. Pengendalian Matriks Austenit Martensit Melalui Proses Perlakuan Panas pada Besi Cor Putih Paduan Chromium Tinggi untuk Material Bola Pelumat. Metal Indonesia. Vol. 33, No. 2. Hal. 94-99.

Huang, X. 2001. The effect of Mo on the structure of high Cr-Mo alloy iron. Journal Material Engineering Perform. Vol. 10(5). Hal. 592-595.

Li, D. 2009. Phase Diagram Calculation of High Chromium Cast Iron and Influence of It's Chemical Composition. Material and Design. Hal. 340-345.

Long, S.Y., Dan, Li., Kun, Z.X. 2006. Optimizing Hardenability of High Chromium White Cast Iron. China Foundry. Vol. 3. No. 4. Hal. 284-287

Pearce, J.T.H. 2002. High-Chromium Cast Irons to Resist Abrasive Wear. Foundryman Vol. 95, No. 4. Hal. 156166

Powell, G., Randle, V. 1997. The effect of Si on the relation between orientation and carbide morphology in high chromium white irons. Journal Material Science. Vol. 32:56
Shofi, A., Astuti, W., dan Nurjaman, F. 2013. Karakteristik Struktur Mikro dan Sifat Mekanik Besi Tuang Putih Paduan Krom Tinggi Hasil Thermal Hardening untuk Aplikasi Grinding Ball. Majalah Metalurgi. V 28.3.2013. Hal. 177-184. 